\title{
A field experimental study on the impact of Acer platanoides, an urban tree invader, on forest ecosystem processes in North America
}

Wei Fang ${ }^{1,2^{*}}$ and Xianzhong Wang ${ }^{3}$

\begin{abstract}
Background: Invasive species affect community dynamics and ecosystem functions, but the mechanisms of their impacts are poorly understood. Hypotheses on invasion impact range from Superior Competitor to Novel Function, from Enemy Escape to Microbial Mediation. In this study, we examined the effects of an urban tree invader, Acer platanoides (Norway maple, NM), on a mesic deciduous forest in contrast to its native congener Acer rubrum (red maple, RM) with a split-plot design experiment. A total of 720 maple seedlings were transplanted to 72 plots under 24 trees of three canopy types. The three experimental treatments were removal of resource competition at above- and belowground and removal of leaf-litter effect. Soil moisture and nitrogen-related microbial activities were followed for each plot.

Results: We found that partial canopy removal increased canopy openness and light transmission to the forest floor, but to a greater extent under NM than under RM trees. NM seedlings were more shade tolerant than RM seedlings in height growth. During the reciprocal transplantation in the mixed forest, biomass accumulation of NM seedlings under RM trees were twice as much as under NM, while that of RM seedlings under NM trees was 23.5\% less than under RM. Soil net nitrification and relative nitrification were significantly higher, but mineralization rate was much lower under NM than under RM trees, which would lead to faster $\mathrm{N}$ leaching and lower $\mathrm{N}$ availability in the soil. Plots with litter removal had significantly higher seedling mortality due to herbivory by the end of 2 years, especially for NM seedlings under NM trees. Trenching enhanced soil water availability but there was no difference among canopy types.
\end{abstract}

Conclusions: Our results demonstrated that invasion of NM not only altered forest canopy structure but also changed herbivory rate for seedlings and $\mathrm{N}$ dynamics in the soils. NM seedlings were more shade tolerant under NM canopies than RM seedlings and were more protected by NM litter under NM canopies than under RM canopies. These altered biotic and abiotic environments will likely facilitate further invasion of NM in the forests, hence positive feedbacks, and make it an increasingly serious tree invader in North America.

Keywords: Norway maple (Acer platanoides), Urban tree, Invasive species, Red maple (Acer rubrum), Ecosystem processes, Canopy and belowground competition, Biomass production, Soil N mineralization and nitrification, Seedling herbivory, Soil microbial communities

\footnotetext{
* Correspondence: wei.fang@qc.cuny.edu

'Department of Ecology and Evolution, Stony Brook University, 650 Life

Sciences Building, Stony Brook, New York 11794, USA

2Present address: School of Earth and Environmental Sciences, Queens

College, City University of New York, 65-30 Kissena Boulevard, Flushing, New

York 11367, USA

Full list of author information is available at the end of the article
} 


\section{Background}

Exotic plant species are a major component of the global changes that can cause fundamental changes in native communities and ecosystems (Parker et al. 1999; Mack et al. 2000; Cronk and Fuller 2001; Ehrenfeld 2003; Dukes et al. 2009; Carón et al. 2015a; Peng et al. 2019). It has been well-documented that ecosystem processes respond to the composition of plant community, which can be significantly altered by the arrival of exotic invasive species (Musil 1993; Evans et al. 2001; Mack et al. 2001; Meekins and McCarthy 2001; Scott et al. 2001; Ehrenfeld et al. 2005; Grant and Paschke 2012; Jo et al. 2017). Plant-driven changes in community composition and ecosystem processes could create feedback mechanisms that may increase the impact on and invasibility of the ecosystem (Ehrenfeld and Scott 2001; Fine 2002; Levine et al. 2006; Suding et al. 2013; Shouman et al. 2017). Such feedbacks will have important ramifications for the management of invasive species and restoration of native communities. The extent of the mutual feedback between the invasive species and the affected communities is, however, poorly understood (Levine et al. 2003; Gomez-Aparicio et al. 2008; Levine et al. 2006; Von Holle et al. 2003). It is therefore essential to quantify the feedbacks and elucidate the mechanisms to improve our understanding of the impact of invasive species on native communities, many of which are undergoing significant changes as a consequence of invasion by exotic plant species.

The global show of climate change and urbanization is staged in every local theater of ecosystem with its own crew of exotic invasive species, which provides great opportunities to address the fundamental question about the role of a single species in community dynamics and ecosystem functions. Assessing the impact of individual invasive species on the recipient community will provide a mechanistic foundation for understanding the structure and dynamics of the affected community (Vitousek 1990), but the mechanisms by which ecosystem processes are affected by plant invaders have traditionally been examined without consideration of the identity of constituent species (O'Neill et al. 1977; Vitousek 2012). Recent cases of biological invasion by exotic species have underscored the importance of a single species in the processes and functions of an entire ecosystem (Ehrenfeld 2010; Bauer 2012; Walsh et al. 2016). Invading species have been shown to alter carbon $(\mathrm{C})$ and nitrogen (N) cycling in a wide range of ecosystems, although the extent of the impact strongly depend on the functional group of the invading species and the habitats the invasive species are perpetrating (Ehrenfeld 2003; Liao et al. 2008; Jo et al. 2017; Grant and Paschke 2012). Another commonly used approach in studying responses of terrestrial communities to plant invasion is to focus on individual organisms without considering the underlying ecosystem processes (Ehrenfeld et al. 2001). It is being increasingly realized that it is important to use universal currencies, such as energy and nutrients, to connect the components of a complex biological system as affected by non-native species (Bolker et al. 1995; Finzi et al. 1998).

Although the mechanisms of the impacts of invasive species are not fully understood, it is obvious that the invasion of a single species in an ecosystem can impact its function and processes through multiple means. Resource availability in the ecosystem can be altered by the newly arrived invader, which may be a better competitor than the native species (superior competitor hypothesis, or $\mathrm{SCH}$ ). Alternatively, other properties of the ecosystem, such as species richness and community structure, can be altered directly by the invader (novel function hypothesis, or NFH). The measurement of the impact on the ecosystem, however, is less than straightforward. Recent studies also suggested that exotic species have escaped their natural enemies from their original habitats that have rendered them advantages in new habitats (enemy release hypothesis, ERH) (e.g., Cincotta et al. 2009; Adams et al. 2009), while effect of biocontrol agent on reducing foliage of invasive plants causes substantial reductions in growth and reproduction (Center et al. 2012). Another type of feedback between plant species and the environment is that the microbial communities under each species might be different and have different feedback effects on the two species (microbial mediation hypothesis, MMH) (e.g., Kandlikar et al. 2019). While much of the effort in assessing an ecosystem affected by invaders has shifted from anecdotal to quantitative, most of these studies attempt to quantify impacts by comparing one site before and after an invasion, or by comparing different sites with and without invasion (Vitousek et al. 1997). The drawback of such an approach is that it is hard to attribute differences to one specific factor, such as the invasion of one species, because other environmental conditions may co-vary with the presence of invaders or the differences may be caused by preexisting factors (Sher et al. 2002).

In this study, we used a field manipulative experiment to circumvent this problem and examined the ecological effects of an urban tree invader, Acer platanoides (Norway maple, hereafter referred to as NM) on ecosystem processes of a deciduous forest dominated by its native congener, Acer rubrum (red maple, hereafter referred to as RM). Because RM itself is a widely distributed generalist and has increased its distribution dramatically in forests of eastern North America over the twentieth century (Abrams 1992, 1998), an examination of these two ecologically successful congeneric species that share a number of ecophysiological characteristics 
(e.g., shade-tolerance) in the same location will help elucidate how an exotic tree invader impacts the dynamics and processes of a forest ecosystem. NM was first introduced to the USA in the 1760s as an ornamental shade tree and became an extremely popular street and landscape tree in North America due to its rapid rate of growth, symmetrically round crown in addition to being tolerant of poor soils and polluted urban environment. NM has also been reported to be associated with lower plant diversity (Webb and Kaunzinger 1993) and potential invade intact forests (Martin 1999; Fang 2005; Martin and Marks 2006).

We tested the superior competitor hypothesis by hypothesizing that NM would be better able to extract and utilize resources and at the same time reduce resource availability to RM individuals. The altered environment will thus be conducive to the growth of the exotic NM trees but suppressing the growth of the native RM trees. We further hypothesized that experimental manipulation, such as canopy removal, trenching, and litter removal, would enhance resource availability to understory seedlings and thus lead to improved seedling performance in both the exotic and native species. In the meantime, we measured ecosystem properties such as light availability, soil $\mathrm{N}$-related microbial activities, soil moisture, and other soil physical and chemical properties, so that alternative hypotheses of invasion impact could be indirectly tested.

\section{Methods}

\section{Study site}

The study was conducted in Muttontown Nature Preserve in Nassau County, New York, USA $\left(40.83^{\circ} \mathrm{N}\right.$, $\left.106.47^{\circ} \mathrm{W}\right)$, where a mesic hardwood forest is commonly found (Fig. 1). The Nature Preserve was a private estate and converted to a county preserve in the mid-1930s (Al Linburg, personal communication). Dominant tree species in this forest are Quercus rubra, Quercus velutina, Acer rubrum, Betula lenta, Cornus florida, Sassafras albidum, Carya glabra, and Carya laciniosa. The shrub layer is dominated by Viburnum acerifolium, Viburnum dentatum, Vaccinium vacillans, and Gaylussacia baccata. Common species in the herb layer include Maianthemum canadense, Parthenocissus quinquefolia, Polygonatum biflorum, Smilacina racemosa, Smilax rotundifolia, and Aster divaricatus. All of these species are native to North America.

NM was initially planted around the 1920s near the southwest border of the preserve and expanded eastwards naturally at least since the 1980s (Al Linburg, personal communication), resulting in one monospecific patch of NM at the southwest corner of the Nature Preserve that covers approximately 1 ha of area. At the time of this study, the NM trees were approximately 6070 years of age. The upperstory in this patch is void of the common native tree species and the understory is dominated by NM saplings and seedlings. Lonicera japonica and Alliaria petiolata, two major exotic invasive species in the eastern US, are also found in the understory. The area adjacent to the NM patch is a mixed forest consisting of NM and native RM. The soils in the three forests (i.e., monospecific NM, mixed NM and RM, and intact RM forests, Fig. 1) were measured to have similar textures with $56.6-62.7 \%$ sand, $29.2-33.3 \%$ silt, and 8.1-9.9\% clay. The Nature Preserve, which contains three distinct patches of forests growing in

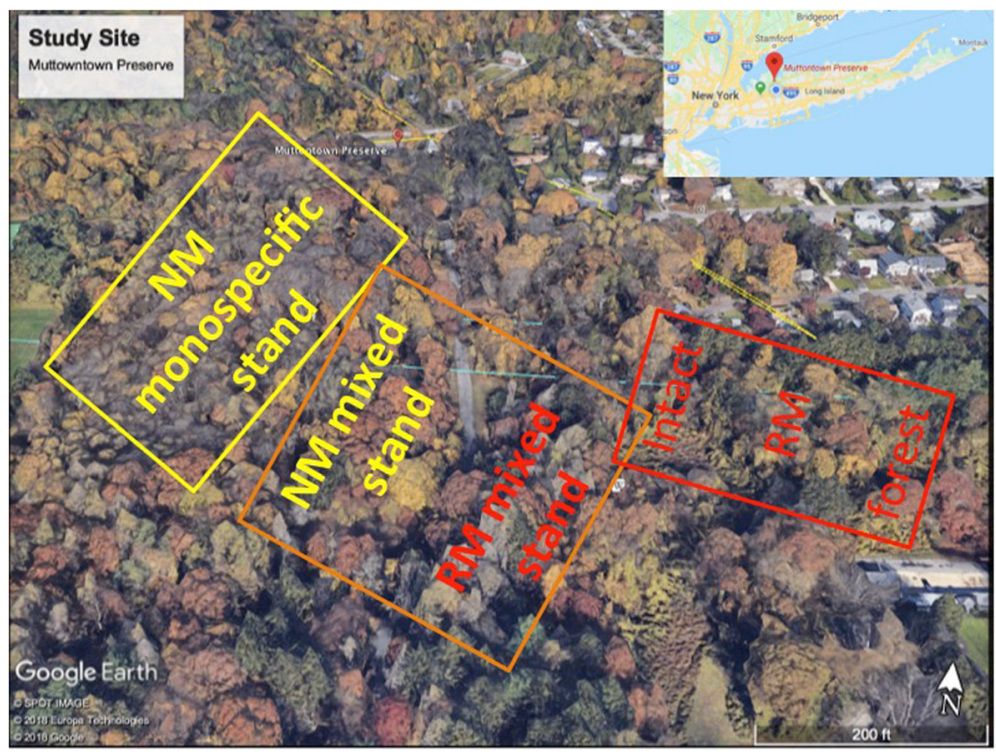

Fig. 1 Distribution of three types of forest patches at Muttontown Nature Preserve, NY, USA (Imagery @2018 Google. Map data @2019 Google) 
texturally similar soils, thus provides an ideal field site to examine the mechanisms of invasion impact of an urban tree on the ecosystem dynamics and processes in the mesic hardwood forests of the eastern US (Fang 2005; Fang and Wang 2011).

\section{Experimental design}

The experiment had a split-plot design with the three dominant tree types as the whole plot factors. The three tree types are NM in the monospecific stand (hereafter referred to as $\mathrm{NM}_{\text {mon }}$ ), $\mathrm{NM}$ in the mixed stand (hereafter referred to as $\mathrm{NM}_{\text {mix }}$ ), and $\mathrm{RM}$ in the mixed forest (hereafter referred to as $\mathrm{RM}_{\text {mix }}$ ). $\mathrm{RM}$ in intact forest was not included in the experiment because we could not get a permit for canopy manipulation. Eight adult trees of each type with comparable sizes $(\mathrm{DBH}=25.4-$ $55.7 \mathrm{~cm}$ for $\mathrm{NM}_{\text {mon }}, 25.5-57.7 \mathrm{~cm}$ for $\mathrm{NM}_{\text {mix }}$, and 19.4$54.8 \mathrm{~cm}$ for $\mathrm{RM}_{\text {mix }}$ ) and distances from each other (12$44 \mathrm{~m}$ for $\mathrm{NM}_{\text {mon }}, 13.5-40 \mathrm{~m}$ for $\mathrm{NM}_{\text {mix }}$, and 10-16 m for $\mathrm{RM}_{\text {mix }}$ ) were chosen for the study, thus yielding a total of $16 \mathrm{NM}$ and eight RM trees. At the beginning of the experiment, four of the eight trees for each type were randomly chosen for removal of the southern half of the canopy (hereafter referred to as Gap) in contrast to those whose canopy remained intact (hereafter referred to as Intact). The purpose of removing the southern half of the canopy was to maximize sunlight penetration to the forest floor while keeping roots of the treated trees alive.

Three $1.5 \mathrm{~m} \times 1.5 \mathrm{~m}$ plots were set up to the south of the trunk of each focal tree to receive plot-level treatments: control, trenching, and litter removal. The plotlevel treatments were first established in mid-May, 2000, prior to the experiment and repeated in the second growing season of 2001. The trenching treatment was used to remove root competition from neighboring adults with the transplanted seedlings in the plots. Trenching was carried out by slicing the edges of the treated plots using a flat shovel to a depth of $30 \mathrm{~cm}$, which is about the maximum root depth of 2-year-old NM transplants. All living roots were manually severed around the trenched plots using axes and saws.

NM and RM seedlings for the transplanting experiment were grown from seeds collected from Muttontown Nature Preserve in 1999. Seedlings of four other woody species and two herbaceous species were also transplanted, but will not be included in this paper. Seeds were stratified and germinated in a greenhouse at the Stony Brook University in the winter of 1999 and spring of 2000. After germination, seedlings were transferred to tree seedling pots ( $2.5 \mathrm{~cm}$ diameter, $12 \mathrm{~cm}$ deep) containing a 3:1 mixture of potting soil and vermiculite in early 2000 in the greenhouse. They were acclimated outside the greenhouse and measured for heights before being randomly assigned and transplanted to the experimental plots from May 24 to June 7, 2000. Dead, sick, or heavily browsed seedlings (about $8.4 \%$ of the total) were replaced with healthy ones within 1 month of transplanting. Seedlings were watered 5 weeks after transplanting.

Statistically, the experiment was a randomized block design. The experimental blocks were the three tree types with the canopy either removed or intact. Tree type and canopy removal were thus whole plot effects and plot-level treatments (control, trenching, and litter removal) were split-plot effects. In all, the study consisted of 72 experimental plots, i.e., three tree types $\times$ eight trees of each type (four trees with canopy halved and four trees with canopy intact) $\times$ three plot-level treatments.

\section{Measurements and data analyses Light availability}

Canopy structure and light transmission in the canopy were measured and calculated using photographic techniques. True-color fisheye photographs were taken on August 24, 2000, in each of the 72 experimental plots using a Nikon MF-12 camera (Nikon Inc., Melville, New York, USA) with Sigma fisheye lens attached.

Photograph negatives were scanned using a HewlettPackard scanner (Hewlett-Packard, Palo Alto, California, USA) and saved as jpeg files with a resolution of 1200 dots per inch. The Gap Light Analyzer (GLA) Program was used to analyze the photo images as described in Frazer et al. (1999). In the final analysis, a threshold of 250-255 was chosen for all gaps and 240-250 for intact canopies (the maximum possible is 256 for the GLA program).

After processing of the images in GLA, both canopy structure and light transmission were calculated for each plot. Three indices of canopy structure, canopy openness (\%), LAI4 Ring, and LAI5 Ring, were used in a multivariate analysis of variance (MANOVA) to test the significance of treatment effects. Canopy openness (\%) is the proportion of the total sky area found in canopy gaps for each sky region. Canopy openness was arcsinetransformed prior to the final MANOVA (Sokal and Rohlf 2003). LAI4 Ring is the effective leaf area index (LAI) integrated over the zenith angle of 0 to 60 degrees (Stenburg et al. 1994), while LAI5 Ring is the effective LAI integrated over the zenith angle of 0 to $75^{\circ}$ (Welles and Norman 1991). Three indices of light transmission (mol photons $\mathrm{m}^{-2} \mathrm{day}^{-1}$ ) were used in another MANOVA to test the significance of treatment effects. These indices were used to measure the absolute amounts of direct, diffuse, and total solar radiation transmitted through the canopy over a growing season.

A detailed description of light availability measurement and results of data analyses were published in Fang 
and Wang (2011) and figures listed in Table 1 will be recited for hypothesis testing and discussion.

\section{Nitrogen transformation and moisture content in the soil}

To capture the short-term in situ dynamics of soil $\mathrm{N}$ transformations as affected by experimental treatments, rates of nitrification and mineralization were measured using a modification of a commonly used method (Adams and Attiwill 1982; Raison et al. 1987; Hart et al. 1994; Robertson et al. 1999). Two adjacent soil cores were taken using a soil corer $(5 \mathrm{~cm}$ inner diameter $x$ $7.5 \mathrm{~cm}$ long) at the beginning of May, July, and September of 2001 in each experimental plot. We sampled soil to a depth of $7.5 \mathrm{~cm}$ to focus on the effect of focal species on soil processes (Peter Groffman, personal communication). Soil samples were individually wrapped with care using double layers of Ziploc bags to keep the samples aerobic and maintain the initial soil moisture. This technique also made it possible to keep the soil profile intact. Soil samples from one of the two paired cores were immediately processed to be analyzed for initial $N$ values, while the other ones were returned to the ground for in situ incubation. After 30 days of incubation, these soil samples were processed for assessing the final $\mathrm{N}$ status and calculating rates of $\mathrm{N}$ transformation.

At the time of soil analysis, soil samples were weighed using a Sartorius top-loading balance and sieved using $2 \mathrm{~mm}$ soil sieves. Ten grams of soil per sample (fresh weight) were immediately extracted with $30 \mathrm{ml}$ of $2 \mathrm{M}$ KCL for $1 \mathrm{~h}$ on a reciprocating shaker at 180 strokes per minute (Eberbach Corp., Ann Arbor, Michigan, USA). The soil slurry was then filtered through Whatman 42 ash free filter paper, acidified to $\mathrm{pH} 2$, and refrigerated at $4{ }^{\circ} \mathrm{C}$. The extracts were analyzed for inorganic $\mathrm{N}$ at the Biochemistry Laboratory in the Center for Watershed Research, University of Louisville (Louisville, Kentucky, USA).

Net $\mathrm{N}$ mineralization rate was calculated as the average daily net increase in ammonium $\left(\mathrm{NH}_{4}{ }^{+}\right)$and nitrate $\left(\mathrm{NO}_{3}{ }^{-}\right)$in the soil $\left(\mathrm{mg} \mathrm{N} \mathrm{kg}{ }^{-1} \mathrm{day}^{-1}\right)$. Nitrification was expressed as both net nitrification (average daily net increase in nitrate in soil, $\mathrm{mg} \mathrm{N} \mathrm{kg}^{-1}$ day $^{-1}$ ) and relative nitrification (proportion of the net rate of nitrate increase over net mineralization). Repeated-measure ANOVA were used to test the significance of treatment effects (von Ende 2001), while relative nitrification was arcsine-transformed prior to ANOVA (Sokal and Rohlf 2003).

During the sampling process for $\mathrm{N}$ mineralization over the growing season of 2001, soil gravimetric moisture of each soil sample was measured three times as described in Jarrell et al. (1999). The measurements were taken 1 day (July), 3 days (May), and 7 days (September) after a saturating rain event to construct soil drying curves. Statistical analysis was conducted using repeatedmeasure ANOVA on the arcsine-transformed moisture levels (von Ende 2001).

\section{Other soil physical and chemical properties}

On May 5, 2001, one surface soil sample $(0-7.5 \mathrm{~cm})$ was taken from each of 72 experimental plots. Samples were sieved through $2 \mathrm{~mm}$ sieve and air-dried for 7 days. Soil organic matter (SOM) was measured in Marine Science Center of SUNY Stony Brook. About 200 g soil subsample from each of 72 plots was sent to the Soil and Plant Tissue Testing Lab of University of Massachusetts for a standard test for soil physical and chemical properties. The soil test results included soil $\mathrm{pH}$, cation exchange capacity (CEC), and percentage base saturation $(\mathrm{K}, \mathrm{Ca}$, and $\mathrm{Mg})$; major nutrients $(\mathrm{ppm})(\mathrm{N}, \mathrm{P}, \mathrm{K}, \mathrm{Ca}$, and $\mathrm{Mg}$ ); micronutrients (ppm) ( $\mathrm{Fe}, \mathrm{Mn}, \mathrm{Zn}, \mathrm{Cu}$ and $\mathrm{B})$; $\mathrm{Al}(\mathrm{ppm})$; and toxic heavy metals (ppm) $(\mathrm{Pb}, \mathrm{Cd}, \mathrm{Ni}$ and $\mathrm{Cr}$ ). All graphs were produced using SigmaPlot 10 (Systat Software Inc., Richmond, California, USA).

\section{Survival and growth of NM and RM seedlings}

Survival and aboveground heights of transplanted seedlings were measured 2 months (late July) and 4 months (late September) following transplanting. Seedling survival and heights (the distance between the cotyledon

Table 1 Published data (from Fang and Wang 2011) to be recited for hypothesis testing and discussion in this study

\begin{tabular}{ll}
\hline Fig. 1 & $\begin{array}{l}\text { Canopy openness (\%) and effective leaf area index in intact canopies and newly created gaps under various combinations of dominant } \\
\text { tree types and canopy treatments. }\end{array}$ \\
Fig. 2 & $\begin{array}{l}\text { Direct, diffuse, and total transmitted light in intact canopies and newly created gaps under various combinations of dominant tree types } \\
\text { and canopy treatments. }\end{array}$ \\
Fig. 3 & $\begin{array}{l}\text { Seedling height of Norway maple and red maple seedlings and relative height growth under different combinations of dominant tree } \\
\text { type and canopy treatments over two growing seasons. }\end{array}$ \\
Fig. 4 & Type III regression of seedling relative height growth against canopy openness (\%) in Norway maple and red maple seedlings. \\
Fig. 5 & $\begin{array}{l}\text { Root, stem and leaf biomass of Norway maple and red maple seedlings grown under RMmix, NMmix and NMmon with intact canopies } \\
\text { and gaps. }\end{array}$ \\
Fig. $6 \quad$ Percentage change in total biomass production of Norway maple and red maple seedlings under various tree types and canopy treatments. \\
Fig. $7 \quad$ Type III regression of biomass allocation against canopy openness $(a, b)$ and biomass allocation of seedlings grown under three canopies (c, d).
\end{tabular}


scale and the tip of the apical bud) were measured again in late June 2001 and late August 2001 in the second growing season. All living seedlings were harvested before leaf senescence from late August to early September 2001. Seedlings were carefully excavated and soil gently shook off the roots. Spray bottle of distilled water was used to remove any remaining soil on the roots after shaking. Leaves, stems, and roots of the seedlings were dried for $48 \mathrm{~h}$ at $65^{\circ} \mathrm{C}$ and weighted to the nearest milligram.

Seedling survivals and their 95\% confidence intervals over the periods of experiments were first calculated and graphed using Kaplan-Meir Life-Test (Proc LIFETEST in SAS; Allison 1995). Survival among treatments and their interactions were tested with likelihood ratio Chisquare tests using logistic regression (Proc GENMOD in SAS) (Stokes et al. 1995). Because seedling mortality events happened continuously between censuses, and because the limited numbers of censuses on large numbers of seedlings yielded many ties in the data, maximum likelihood with a complementary log-log model was used for the logistic regression in the GENMOD procedure (Allison 1995).

Stepwise multiple regressions were used to examine growth responses of NM and RM seedlings to various degrees of canopy openness in the three types of focal trees. Three variables indicating seedling performance were used in the analyses, i.e., biomass accumulation, relative growth (measured as log transformed ratio of final seedling height to initial height), and ratio of belowground to aboveground biomass (root:shoot ratio). Detailed results of seedling growth were published in Fang and Wang (2011) (Table 1).

\section{Statistical analysis}

Stepwise multiple regression was used to examine the seedling responses to resource availability and soil properties. Three dependent variables indicating seedling performance were used in the analyses: relative growth, i.e., $\log$ transformed seedling final to initial height ratio, final biomass, and R/S biomass ratio. Groups of independent variables included soil organic matter, soil $\mathrm{Al}$ concentration, soil total lead concentration, cation exchange capacity, cation \% saturation $(\mathrm{K}, \mathrm{Mg}, \mathrm{Ca})$, soil macronutrient concentrations $\left(\mathrm{P}, \mathrm{K}, \mathrm{Ca}, \mathrm{Mg}, \mathrm{NH}_{4}{ }^{+}\right.$, and $\mathrm{NO}_{3}{ }^{-}$), soil micronutrient concentrations ( $\mathrm{B}, \mathrm{Mn}, \mathrm{Zn}$, $\mathrm{Cu}$, and $\mathrm{Fe}$ ), soil $\mathrm{N}$-mineralization and nitrification $\left(\Delta \mathrm{NH}_{4}{ }^{+}\right.$and $\Delta \mathrm{NO}_{3}{ }^{-}$in three mineralization periods), soil moisture (three measures), canopy structure (\% canopy openness, LAI4, LAI5), and light availability (direct, diffuse, and total transmitted light).

Separate multivariate regression by species was also used to detect differences of performance (including height relative growth, biomass accumulation, and allocation patterns) among different seedling species.

\section{Results}

\section{Canopy properties and light transmission}

Canopy openness (\%) and effective leaf area index (LAI) differed significantly among dominant tree types $(p<0.01)$ and canopy treatments $(p<0.001)$, and the interaction between these two treatments was marginally significant $(p=$ 0.056). Removal of half the canopies from the focal trees greatly increased canopy openness and reduced effective LAIs. $\mathrm{NM}_{\text {mon }}$ had the greatest increase in canopy openness $(+243.7 \%)$ and largest decrease in LAI4Ring $(-49.0 \%)$ and LAI5Ring $(-47.0 \%)$, the effective LAIs integrated over zenith angles of $0-60$ and $0-75^{\circ}$, respectively. The quantity of transmitted light to forest floors was affected by tree types and canopy treatments in a similar pattern.

Canopy removal had significant effect on transmitted light $(p<0.001)$, but the effects were only marginal for dominant tree types $(p=0.052)$ and for the interactions between these two treatments $(p=0.063)$. The amount of direct, diffuse, and total transmitted light was similar among the three dominant tree types under intact canopies. Increase in total transmitted light with canopy removal was much greater under $\mathrm{NM}_{\text {mon }}(313.9 \%)$ than under $\mathrm{RM}_{\text {mix }}$ and $\mathrm{NM}_{\text {mix }}(153.4 \%$ and $147.5 \%$, respectively).

\section{Rates of mineralization and nitrification}

Net $\mathrm{N}$ mineralization rate was significantly lower in the soil under the exotic NM adults than under the native RM adults in July, the peak of physiological activities for trees in the forests at the study site $(p=0.035$, Fig. 2a). In contrast, net nitrification rate was significantly higher in soils under NM adults than under RM adults throughout the growing season, regardless of whether the NM adults were in monospecific stands or mixed with RM adults $(p<0.001$, Fig. $2 \mathrm{~b})$. Relative nitrification, defined as the ratio of nitrification to mineralization rate, ranged from 0.74 to 0.87 in soils under NM adults, while relative nitrification was much lower in soils under RM adults with a range of $0.30-0.37$ (Fig. 2c).

Soil N transformations also responded to plot-level treatments, i.e., litter removal and trenching. Mineralization rates were significantly lower in the litter-removed plots than in the trenched plots throughout the growing season as revealed by repeated-measure ANOVA $(p=0.002)$ (Fig. 3a). A similar trend was observed for nitrification rate, which was lower in the litter-removed plots than in the trenched plots throughout the season (Fig. 3b). Because of the similar seasonal changes in mineralization and nitrification rates in plots of the three plot-level treatments, the relative nitrification, i.e., $\left(\mathrm{NO}_{3}{ }^{-}\right) /\left(\mathrm{NO}_{3}{ }^{-}+\mathrm{NH}_{4}{ }^{+}\right)$, was unaffected by either litter removal or trenching (Fig. 3c).

\section{Soil drying after rainfall events}

Soils in the trenched plots had significantly higher moisture content than in the control plots and those with 


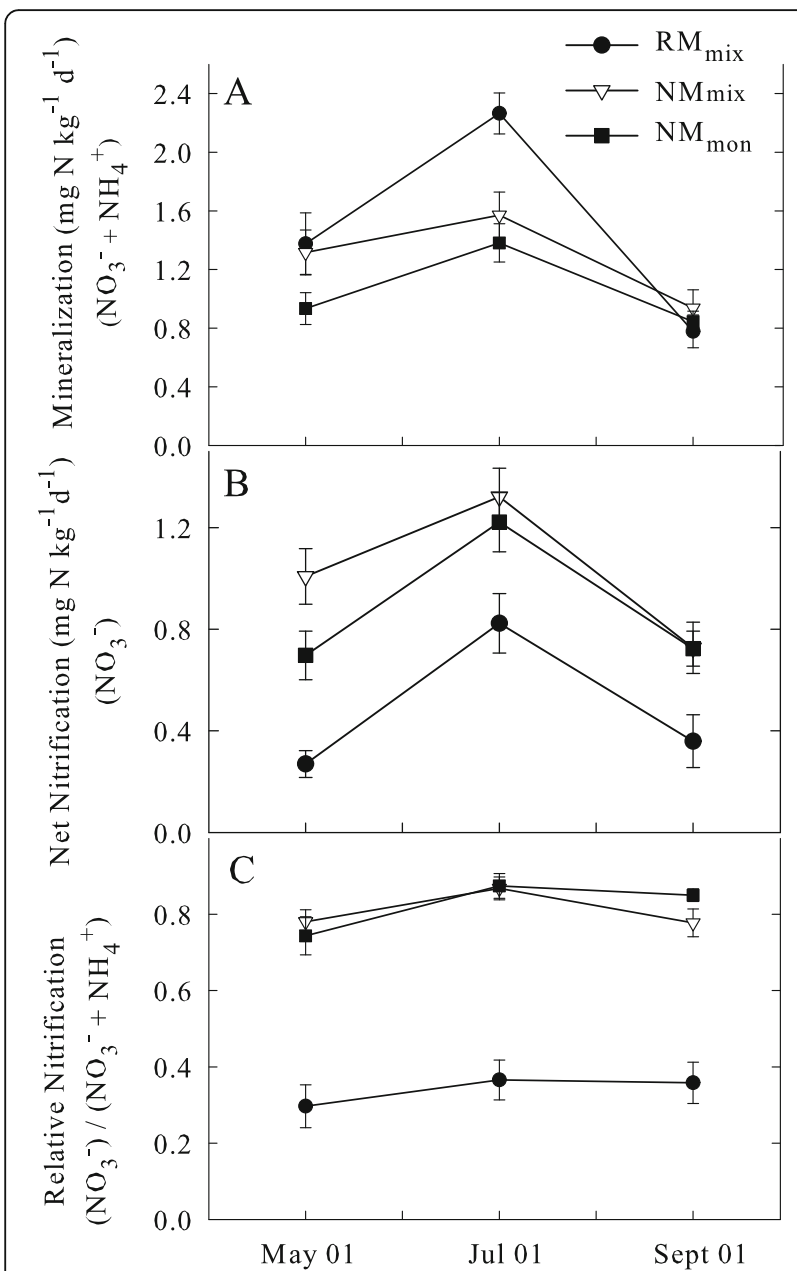

Fig. 2 Mineralization rate (a), nitrification rate (b), and relative nitrification (c) in soils under red maple adults in mixed forest $\left(R M_{\text {mix }}\right)$, Norway maple adults in mixed forest $\left(N M_{\text {mix }}\right)$, and Norway maple adults in monospecific stand $\left(\mathrm{NM}_{\mathrm{mon}}\right)$. The graph shows means $\pm 1 \mathrm{SD}$

litter removed 1 day $(p=0.041)$ and 3 days $(p=0.002)$ after a saturating rain event (Fig. 4). No difference in soil moisture was observed among the plot-level treatments 7 days after a rain event $(p=0.819)$. Soil moisture was unaffected by dominant tree types or canopy treatments one, 3 or 7 days after rain events (data not shown).

\section{Other soil physical and chemical properties}

Individual ANOVAs on soil $\mathrm{pH}$, soil organic matter (SOM, \%), cation exchange capacity (CEC), Al concentration, and total lead (ppm) yielded no statistically significant patterns. However, RMmix seemed to have relatively higher SOM (22.85\% vs. $18.54 \%$ and $19.62 \%)$ and CEC (37.02 vs. 33.67 and 32.70) than $\mathrm{NM}_{\text {mix }}$ and $\mathrm{NM}_{\text {mon. }}$. Soil CEC is an important measure of the soil's ability to retain and to supply nutrients. A higher CEC represents a higher primary soil reservoir of readily

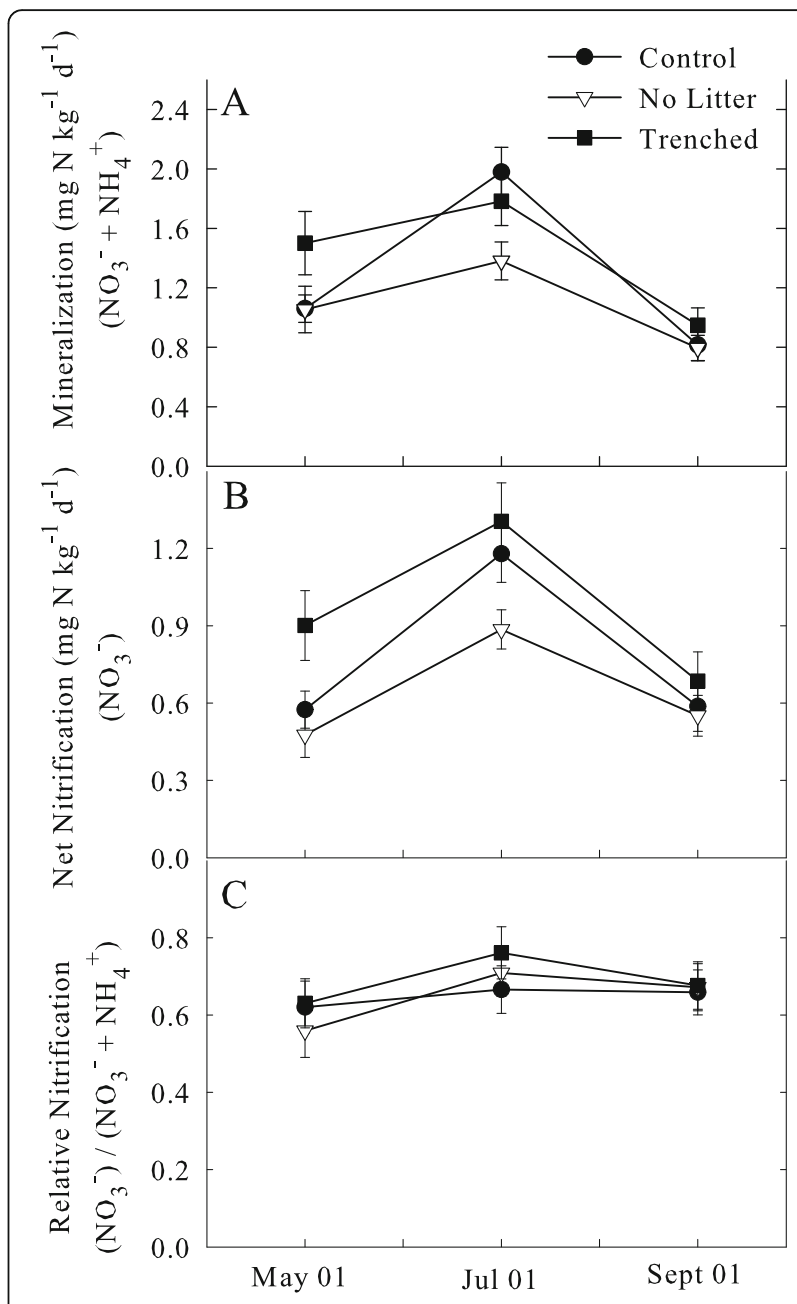

Fig. 3 Mineralization rate (a), nitrification rate (b), and relative nitrification (c) in plots under three plot-level treatments, i.e., control plots (circles), litter-removed plots (triangles), and trenched plots (squares). The graph shows means \pm 1 SD

available $\mathrm{K}, \mathrm{Ca}, \mathrm{Mg}$, and several micronutrients and lower leaching of these elements. Soil Al (122 ppm vs. $94.25 \mathrm{ppm}$ ) and total lead concentration (345.21 ppm vs. $279.35 \mathrm{ppm}$ ) were relatively higher under $\mathrm{NM}_{\text {mix }}$ than under $\mathrm{RM}_{\text {mix }}$, both statistically significant based on Bonferroni $t$ test.

Percent base saturation $(\mathrm{K}, \mathrm{Ca}, \mathrm{Mg})$ was higher in soil samples under $\mathrm{NM}_{\text {mon }}$ and $\mathrm{NM}_{\text {mix }}$ than under $\mathrm{RM}_{\text {mix }}$ $(p=0.006$ for MANOVA). Trenching made more Ca available in the soil while removing litter made less $\mathrm{Ca}$ available ( $p=0.004$ for plot-level effect). There was a significant interaction between dominant tree type and plot-level treatment when considering all three bases together $(p=0.012)$ : trenching had more positive effects under NM adults than under RM adults (Fig. 5). Although the interactions between dominant tree type and plot-level treatment were not significant for $\mathrm{Ca}(p=$ $0.167)$ or $\mathrm{Mg}(p=0.277)$ alone, they shared the tendency 


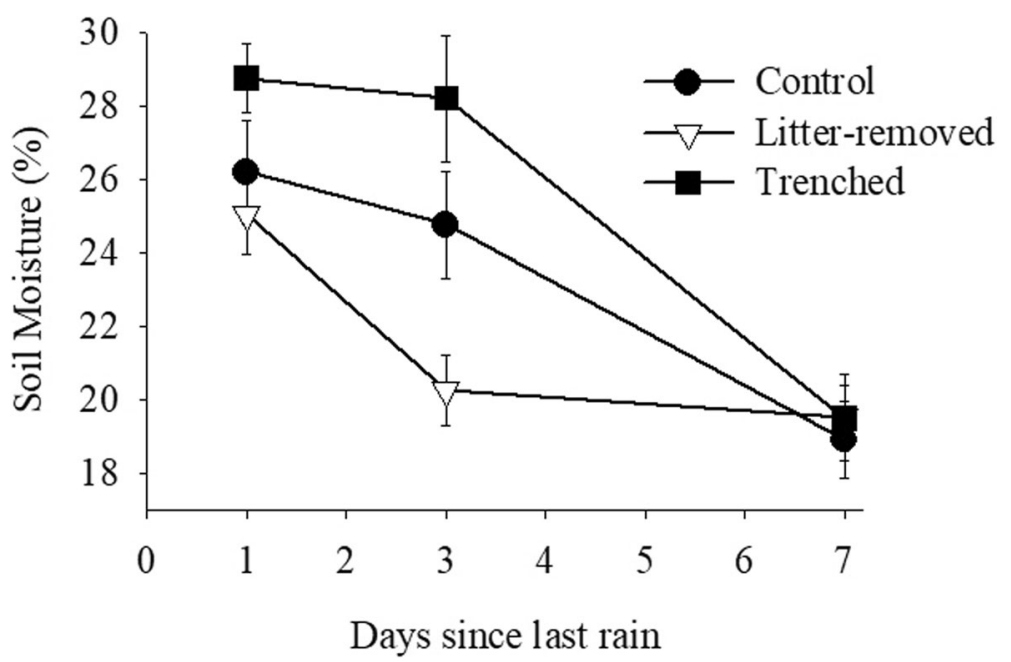

Fig. 4 Moisture content in soils of control plots (circles), litter-removed plots (triangles), and trenched plots (squares) after 1, 3, and 7 days of saturating rain events. The graph shows means \pm 1 SD

of having stronger response to plot-level treatments under NM than under RM. Therefore, collectively, MANOVAs on macro- or micronutrients had significant dominant tree by plot-level treatment interactions.

The MANOVA of soil major nutrients $(\mathrm{P}, \mathrm{K}, \mathrm{Ca}, \mathrm{Mg}$, $\mathrm{NH}_{4}{ }^{+}, \mathrm{NO}_{3}{ }^{-}$) suggested that $\mathrm{RM}_{\text {mix }}$ had significantly smaller nutrient pool than $\mathrm{NM}_{\text {mix }}$ and $\mathrm{NM}_{\text {mon }}(p<$ $0.001)$, especially $P$ (7.667 vs. 10.167 and $11.833 \mathrm{ppm})$, $\mathrm{Ca}$ (305.38 vs. 465.2 and $454.42 \mathrm{ppm}), \mathrm{Mg}$ (67.208 vs. 88.542 and $77.958 \mathrm{ppm}$ ), and $\mathrm{NO}_{3}^{-}$(18.792 vs. 52.708 and $37.458 \mathrm{ppm})$. Since the results from N mineralization suggested a higher availability of $\mathrm{N}$ under RM adults over the growing season, a lower pool size may suggest a higher turnover rate of the major nutrients. Available $\mathrm{P}$ also had lower level under gaps than under intact canopies $(9.33 \pm 0.46 \mathrm{ppm}$ vs. $10.44 \pm$ $0.45 \mathrm{ppm})$. A lower level of $\mathrm{P}$ under gaps further suggested that active seedling growth drew down the nutrient pool size. Trenching significantly improved the pool sizes of major nutrients, especially that of $\mathrm{NO}_{3}{ }^{-}$, while litter removal decreased them ( $p=0.009$ for $\mathrm{NO}_{3}{ }^{-}$, and $p=0.024$ for major nutrients altogether) (43.625 $\mathrm{ppm} \mathrm{NO}_{3}{ }^{-}$for trenched plots, $31.625 \mathrm{ppm}$ for litter removed plots). This again suggested that trenching treatment effectively removed root competition for $\mathrm{NO}_{3}{ }^{-}$, while the presence of litter was beneficial to the nutrient pools, partly by preventing leaching. There was a significant interaction between dominant tree type and plot-level treatment when considering all major nutrients together $(p=0.047)$, although the interaction was not significant for any single nutrient alone. Overall, trenching tended to have more positive effects on macronutrient availability under NM adults than under RM adults (e.g., $\mathrm{Ca}$ and $\mathrm{Mg}$ in Fig. 5).
The MANOVA of soil micronutrients (B, $\mathrm{Mn}, \mathrm{Zn}, \mathrm{Cu}$, Fe) also suggested that $\mathrm{RM}_{\text {mix }}$ had smaller nutrient pool than $\mathrm{NM}_{\text {mix }}$ and $\mathrm{NM}_{\text {mon }}(p=0.064)$, especially $\mathrm{Mn}(p=$ $0.035,12.97$ vs. 25.964 and $19.122 \mathrm{ppm})$ and $\mathrm{Zn}(p=$ $0.115,3.475$ vs. 4.271 and $4.782 \mathrm{ppm})$. Trenching
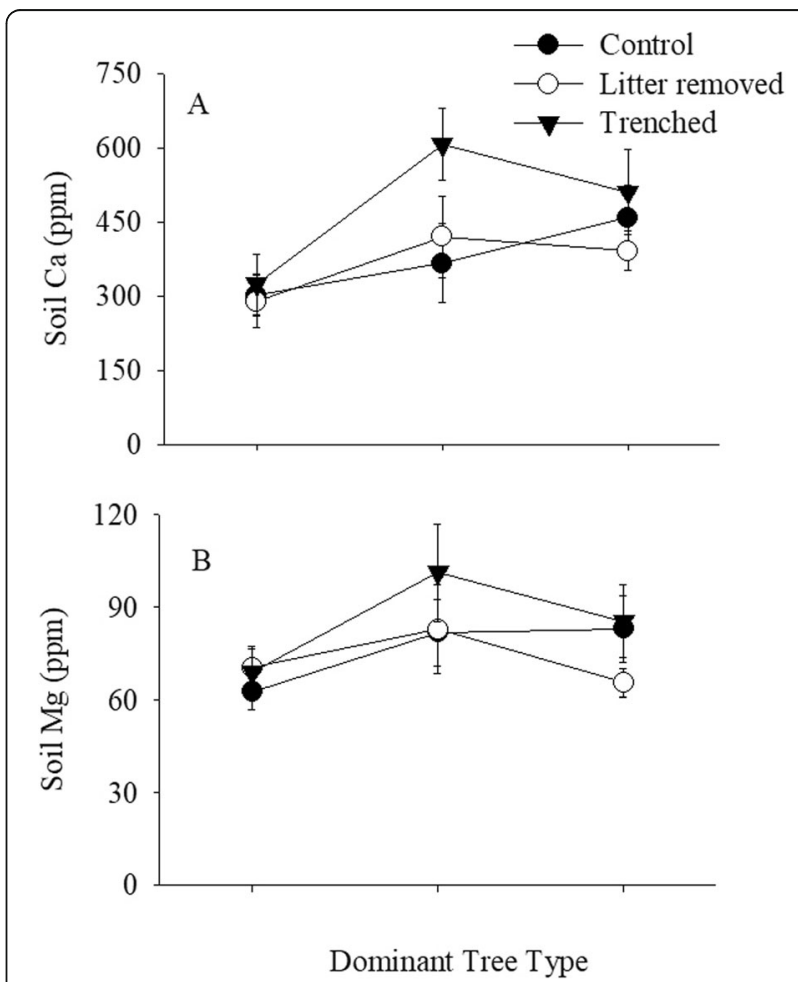

Fig. 5 Soil Ca (a) and Mg (b) availability under different combinations of dominant tree type and plot-level treatment. Circles: control; triangles: litter removed; squares: trenched. The graph shows means \pm 1 SD 
improved the pool sizes of $\mathrm{Mn}$ and $\mathrm{Zn}$, while litter removal decreased them $(p=0.017$ for Mn, with $24.26 \mathrm{ppm}$ for trenched plots and $15.625 \mathrm{ppm}$ for litter removed plots; $p=0.049$ for $\mathrm{Zn}$, with $4636 \mathrm{ppm}$ for trenched plots vs. $3.815 \mathrm{ppm}$ for litter removed plots). There was a marginally significant interaction between dominant tree type and plot-level treatment when considering all minor nutrients together $(p=0.071)$, although the interaction was not significant for any single nutrient alone.

The MANOVA of soil toxic metals (lead, cadmium, nickel, and chromium) suggested a significant difference among dominant tree types $(p=0.006)$, with $\mathrm{RM}_{\text {mix }}$ had lower lead (20.135 ppm vs. 25.893 and $22.253 \mathrm{ppm}$ ) and nickel levels (0.245 ppm vs. 0.317 and $0.275 \mathrm{ppm})$, but higher cadmium level (0.0763 ppm vs. 0.0608 and $0.0533 \mathrm{ppm})$ than $\mathrm{NM}_{\text {mix }}$ and $\mathrm{NM}_{\text {mon. }}$. There was a significant interaction between dominant tree type and plot-level treatment when considering all four toxic metals together $(p=0.049)$, although the interaction was not significant for any single metal alone. Since all of them are far below the levels of being harmful, such comparison may not as biologically meaningful as other comparisons.

\section{Survival of NM and RM seedlings}

Both NM and RM Seedlings survived significantly better under $\mathrm{RM}_{\text {mix }}$ than under $\mathrm{NM}_{\text {mon }}$ and $\mathrm{NM}_{\text {mix }}(p<0.001$, Fig. 6). Canopy removal also significantly enhanced seedling survival $(p<0.001$, Fig. 7$)$. Trenching enhanced seedling survival, while litter removal decreased seedling survival ( $p<0.001$ for plot-level treatment) especially for NM seedlings (Fig. 8). In addition, RM seedlings survived more poorly than NM seedlings in control plots, better than NM seedlings in plots with litter removed, and survived not significantly differently in trenched plots ( $p=0.002$ for Breslow-Day test). Due to severe herbivory-related mortality under NM canopies, NM seedlings had a lower overall survival (60.28\%) than RM (75.00\%), across all treatments combined.

Multivariate regression showed that relative height growth of NM and RM seedlings, measured as the ratio of final to initial height with log transformation, responded differently to canopy openness. The relative height growth showed no response to canopy openness in NM seedlings ( $p=0.0934$ for the regression slope) (Fig. 9a) but showed positive response in RM seedlings $(p<0.0001$ for the regression slope) (Fig. 9b). Relative growth of NM seedlings varied greatly in response to canopy opening under different trees (Fig. 9c). Relative growth of RM seedlings, however, all increased significantly in response to canopy opening (Fig. 9d).

This result on relative (aboveground) height growth, when compared with root/shoot ratio response to
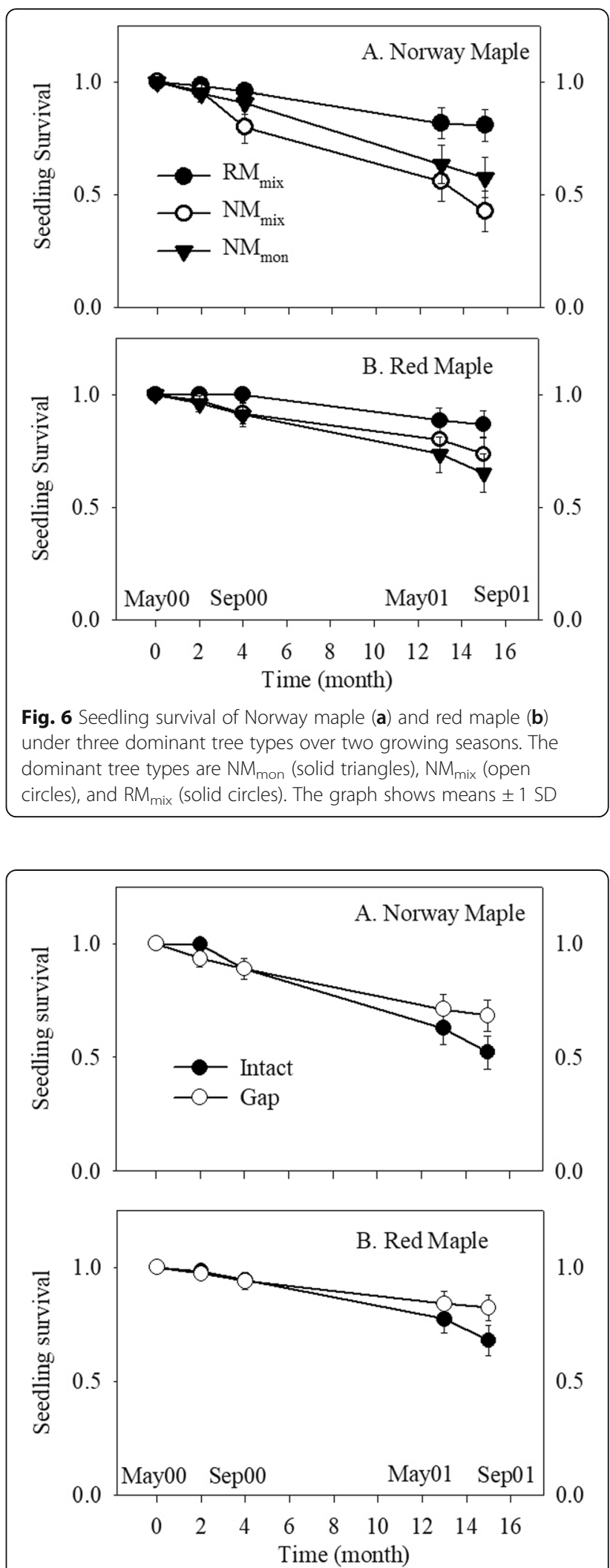

Fig. 7 Seedling survival of Norway maple (a) and red maple (b) with different canopy treatments (intact: solid circles; gap: open circles) over two growing seasons. The graph shows means \pm 1 SD 


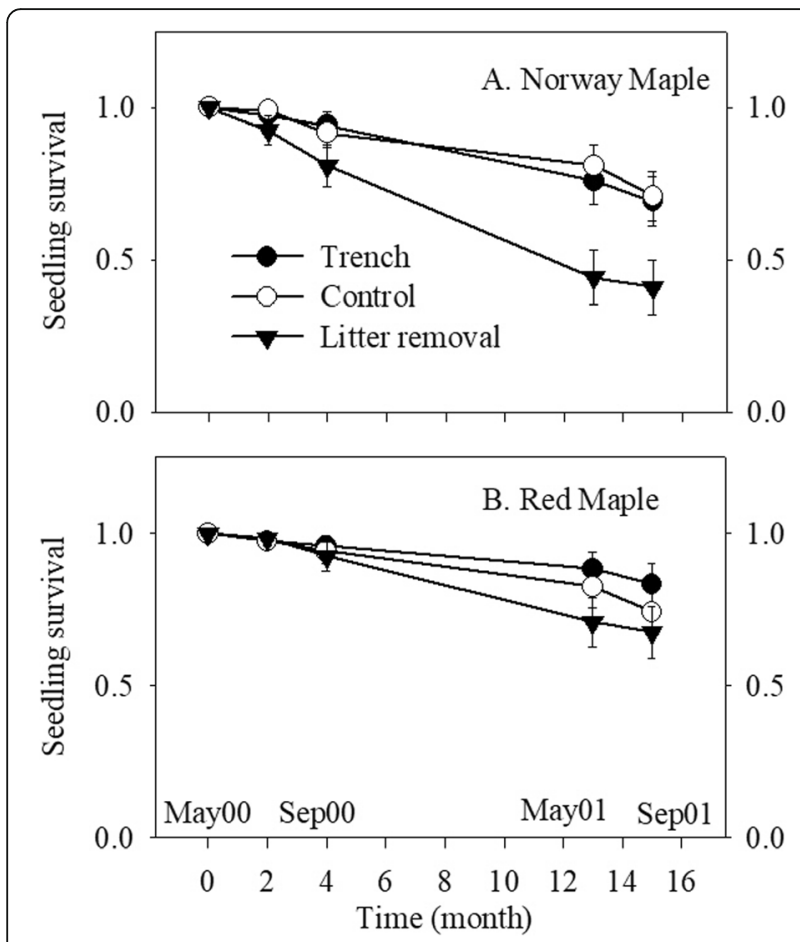

Fig. 8 Seedling survival of Norway maple (a) and red maple (b) with different plot-level treatments (trench: solid circles; control: open circles; litter removal: solid triangles) over two growing seasons. The graph shows means $\pm 1 \mathrm{SD}$

canopy openness (\%) (Table 1, Fig. 7 in Fang and Wang (2011)), suggests a trade-off in resource allocation: the $\mathrm{R} / \mathrm{S}$ ratio of Norway maple seedlings responded to increase of \%canopy openness positively $(p<0.05)$ while $\mathrm{R} / \mathrm{S}$ ratio of red maple did not change with \% canopy openness. In another word, when exposed to higher light availability, Norway maple seedlings responded mostly in belowground growth while red maple seedlings responded mostly in aboveground growth.

\section{Discussion}

\section{Aboveground competition for light?}

One attribute that enables many exotic species to become successful invaders is their ability to deprive native competitors of adequate light for normal functioning. The highly invasive NM seems to possess this attribute. The formation of monospecific NM stands, for example, greatly altered the vertical structures and light environment of the forests. Under the dense canopies of $\mathrm{NM}_{\text {mon }}$ trees, there were almost no sub-canopy saplings or seedlings growing. Under the less dense canopies of $\mathrm{NM}_{\text {mix }}$ or $\mathrm{RM}_{\text {mix }}$ trees, however, there was a mixture of seedlings of NM and native tree species.

In this study, there was a significant interaction between dominant tree type and canopy treatment on light availability. Removing half canopies increased light availability more under NM adults than under RM adults. The pattern of light availability strongly reassembled the pattern of seedling performance (Fang and Wang 2011). This suggested the aboveground competition for light was one mechanism with which NM attained competitive superiority over RM.

It was counter-intuitive to have differential light availability under three dominant tree types after removing the half canopies other than before. This was mainly caused by the difference between monospecific stand and mixed forest. There were almost no sub-canopy trees growing under NM monospecific stand. Therefore, removing half canopies of $\mathrm{NM}$ in $\mathrm{NM}_{\text {mon }}$ opened a larger portion of the sky than doing it on maple adults in mixed forest.

$\mathrm{NM}_{\text {mix }}$ and $\mathrm{RM}_{\text {mix }}$ had very similar canopy structure before and after canopy removals. However, seedling growth responded to canopy removal more positively under $\mathrm{NM}_{\text {mix }}$ than under $\mathrm{RM}_{\text {mix }}$. This strongly suggested that the aboveground of NM adults had stronger competitive effect on the growth of understory seedlings than that of RM adults. $\mathrm{NM}_{\text {mix }}$ gained relatively more direct transmitted light through canopy removal (1.362 vs. $3.841 \mathrm{~mol} \mathrm{~m}^{-2}$ day $\left.^{-1}\right)$ than $\mathrm{RM}_{\text {mix }}$ did (1.171 vs. $3.293 \mathrm{~mol} \mathrm{~m}^{-2}$ day $\left.^{-1}\right)$. This may suggest that the aboveground of NM adults cast stronger suppression over understory than that of RM adults by blocking more direct sunlight.

In terms of seedling growth and biomass accumulation, our results revealed three ecophysiological traits in NM seedlings that apparently contribute to the invasiveness of NM trees in RM-dominated forests. The first is its higher root/shoot ratio in NM seedlings (0.7191.166) than in RM seedlings $(0.568-0.722)$. The second is the NM seedling tolerance to shade (Fig. 9). The third is the responsiveness in root/shoot ratio to canopy opening. At greater canopy openness and hence higher light availability, NM seedlings shifted more biomass belowground. Seedlings of the exotic NM therefore invest a greater proportion of biomass to belowground components when above-ground resources are less limiting and are more plastic in biomass allocation than those of the native RM. A larger root system and greater plasticity in allocation resources will enable NM seedlings to be more competitive than RM seedlings for belowground resources, such as the often limiting inorganic N. The ability of NM to employ these traits may result from the fact that NM does not have to deal with as much leaf damage from insects (Cincotta et al. 2009) and can afford to have higher allocation of energy to roots. There was a lack of interactions between dominant adult tree types and plot-level treatments (e.g., trenching) on $\mathrm{N}$ transformations, suggesting that competition by NM and $\mathrm{RM}$ for $\mathrm{N}$ may be different at the seedling and adult stages. 

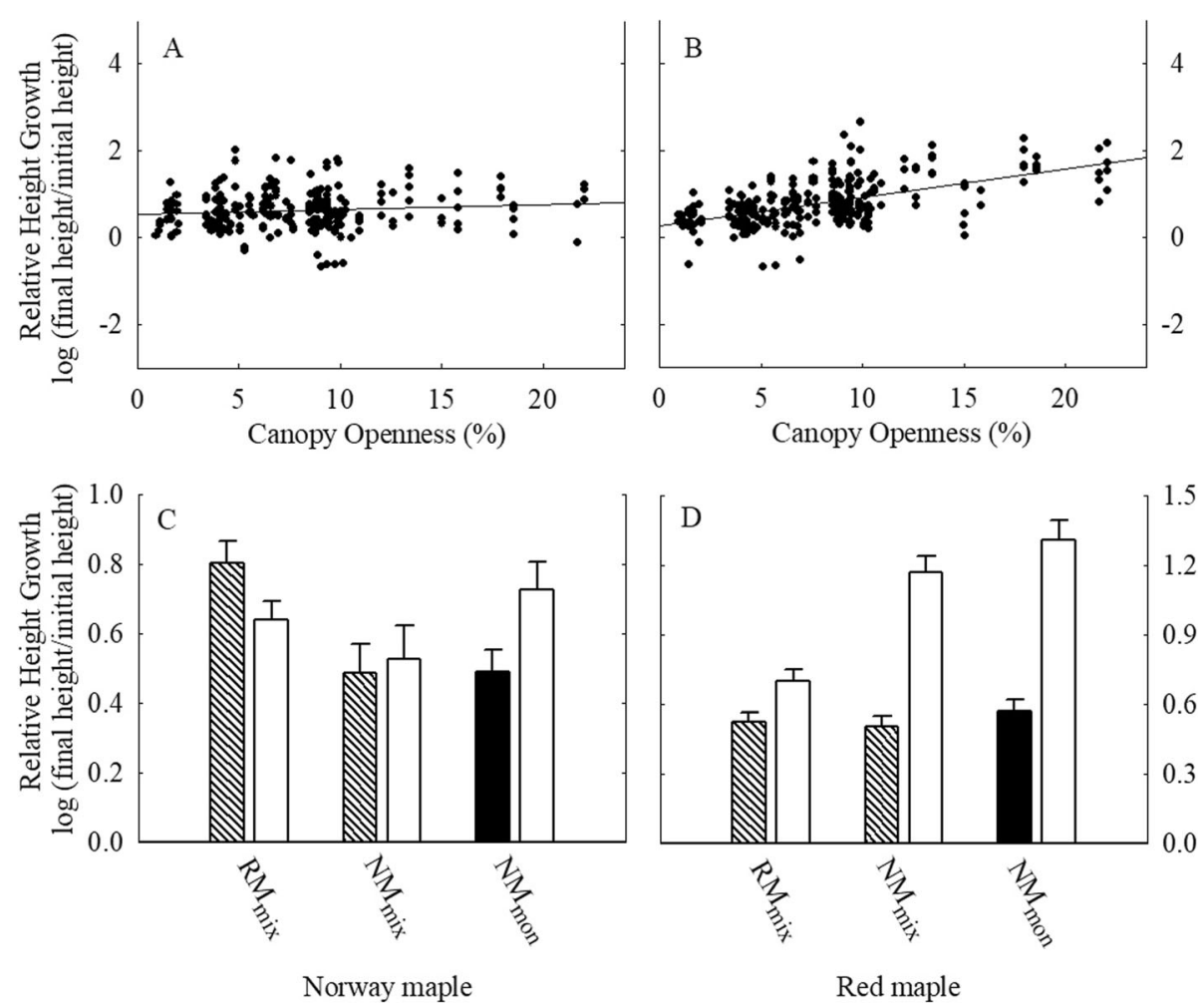

Fig. 9 Relative height growth of Norway maple $(\mathbf{a}, \mathbf{c})$ and red maple (b, d) seedlings over canopy openness (\%) and under three canopies with intact canopies (striped or solid bars) and newly created gaps (open bars). The graph shows means \pm 1 SD

\section{Belowground processes and microbial activities}

A prior study showed that competition could overwhelm the positive plant-soil feedback generated by invasive plants (Crawford and Knight 2017). It is not the case for NM. The presence of NM trees caused significant changes in the dynamics of a number of important belowground processes, most notably $\mathrm{N}$ transformations, in the forests. Mineralization rate was markedly higher in the soil under the native RM than under the exotic $\mathrm{NM}$ trees in the mid-season, indicating that the soil under the native RM adults had a higher capacity than the soil under NM adults to transform organic $\mathrm{N}$ into inorganic forms, resulting in higher supply rate of inorganic $\mathrm{N}$ to all plants. Since the leaf or litter $\mathrm{N}$ concentrations were not measured, it was hard to tell how much leaf $\mathrm{N}$ contributed to the differences in soil $\mathrm{N}$ mineralization rates. On the other hand, a much greater proportion of the mineralized $\mathrm{N}$ was $\mathrm{NO}_{3}{ }^{-}$under $\mathrm{NM}$ trees than under RM trees throughout the season. These results suggest that, after the invasion of NM trees, there would be less inorganic $\mathrm{N}$ available for plant uptake, but greater likelihood of inorganic $\mathrm{N}$ being lost from the plant-soil systems because of the higher relative nitrification.

It has been shown that plant species can greatly alter $\mathrm{N}$ mineralization rate in the soil with the magnitude of the effects depending on the chemical composition of plant tissues (Vitousek and Walker 1989; Wedin and Tilman 1990; Jo et al. 2017). In addition to the varying plant-mediated $\mathrm{N}$ input into the soil, microbial communities in the soil can be altered after the invasion of nonnative species with the degree of alteration dependent on soil properties and magnitude of difference between the native and non-native species (Kourtev et al. 2002; Belnap et al. 2005; Wolfe and Klironomos 2005; Li et al. 2006; Rodgers et al. 2008; Rodrigues et al. 2015; Grant and Paschke 2012; Lau and Suwa 2016). It is therefore not surprising that the effects of invasive species on soil $\mathrm{N}$ dynamics have been found to be not only highly variable but also specific of the invasive species and the habitat being invaded (Ehrenfeld 2003; Liao et al. 2008). From our results, it is clear that NM has the ability to alter soil $\mathrm{N}$ dynamics (e.g., mineralization rate and relative nitrification) in the hardwood forests dominated by its congener RM. These results have important implications for understanding the invasiveness of NM because $\mathrm{N}$ mineralization is the most important determinant of aboveground growth in hardwood forests in North America (Reich et al. 1997). How much of that was caused by coevolution of the soil microbial activities under NM canopies? How would this change their feedback effects on the two maple species? These are 
important questions that are worthy of further investigation.

Plot-level treatment, such as trenching in the soil around a tree, removes root competition for inorganic $\mathrm{N}$ by neighboring trees. An examination of $\mathrm{N}$ dynamics in the trenched plots under different trees allows testing of the hypothesis of whether the exotic NM is a superior competitor for resources in the soil. Our study found no interaction between dominant tree type and plot-level treatment on $\mathrm{N}$ mineralization and nitrification rates, even though there was more abundant mineralized $\mathrm{N}$ available for growth under RM trees, as indicated by the greater mineralization rate in the soil. There was no interaction between the dominant tree types and plotlevel treatments, either. These results suggest that NM adults did not obtain its superior competitive ability in the forests dominated by RM trees through root competition for belowground resources, particularly $\mathrm{N}$ and water.

\section{Effect of NM leaf litter and alternative hypotheses of invasion impact}

There has been speculation about potential allelopathic effects of NM that had led to its monopolistic dominance and alarming bare ground underneath the canopy in some area (Webb and Kaunzinger 1993; Martin 1999; Galbraith-Kent and Handel 2008). Historically, allelopathy is a very difficult subject to study because there are alternative causes that could lead to the same results (Muller 1969) and have to be ruled out first, such as resource competition. Therefore, this experiment was designed to test the $\mathrm{SCH}$ on the one hand, and with the hope of acquiring empirical evidence for allelopathic effects of Norway maple on the other hand. Norway maple could potentially release allelopathic chemicals from the roots, or rain allelopathic chemicals down from the canopy, or from its leaf litter if the allelopathic chemicals in the litter do not degrade with leaf senescence. If the allelopathic chemicals were in the leaf litter, then removal of litter would bring positive effects on the survival and growth of transplanted seedlings.

To the contrary of such prediction, seedlings, especially NM seedlings, had more herbivory-related mortality and growth setback in plots with NM litter removed. We found significantly lower soil water availability, lower mineralization rate, and higher nitrification rate which resulted in lower soil $\mathrm{NO}_{3}{ }^{-}$concentration in plots with litter removed compared to other plots. Although there was less leaf herbivory on NM in the USA than in its native habitat in Europe (Cincotta et al. 2009; Adams et al. 2009), NM is still susceptible to deer browsing and infestation of Asian longhorned beetles.

Although the results of this study suggest that NM trees were able to compete for light resources as adults and tolerate shade as seedlings, the soil microbial community under NM had low mineralization and high nitrification, which had led to $\mathrm{N}$ deprived soil that became less suitable for other species to establish; and NM leaf litter protects the understory seedlings from herbivory, there are many more questions yet to be addressed:

1. Soil under NM trees had lower SOM, lower CEC, higher $\mathrm{Al}$, and total lead concentration than under $\mathrm{RM}$ trees. Trenching released more $\mathrm{Ca}$ and $\mathrm{Mg}$ under NM than under red maple (Fig. 5). Did NM contributed to the development of poorer soil, or did NM simply happen to be planted and get established in soil that was already deprived because of prior human activities?

2. A similar question holds for $\mathrm{N}$-related soil microbial activities (Figs. 2 and 3). Did NM coevolve with soil microbial communities with lower mineralization and higher nitrification rates, or did these communities already exist before the arrival of NM?

3. Soil under NM trees had higher \% base saturation $(\mathrm{K}, \mathrm{Ca}, \mathrm{Mg}$ ), and had a higher pool of major nutrients ( $\mathrm{P}, \mathrm{Ca}, \mathrm{Mg}, \mathrm{NO}_{3}{ }^{-}$) and a higher pool of micronutrients (B, Mn, $\mathrm{Zn}, \mathrm{Cu}, \mathrm{Fe}$ ) than under $\mathrm{RM}$ trees. Did RM canopy and its understories have a more efficient way utilizing nutrients that led to faster turnover rates for the nutrients? Or, might there be some major limiting factor underneath NM preventing all other elements to be utilized?

4. Have NM left all natural enemies behind in Eurasia? What about specialists like Asian longhorned beetles, and generalists like deer and squirrels?

5. Is NM mostly wind pollinated or insect pollinated? What are the specialist and generalist pollinators associated with NM in North America and in Eurasia?

6. What would happen if we transplant other native or exotic, woody, or herbaceous seedlings under experimental setting like this? How would NM facilitate or deter the invasion of other exotic plants such as the notorious vines Lonicera japonica and Celastrus orbiculata?

\section{Conclusions}

Our field study revealed that the high invasiveness of NM can be attributed to its dense canopy, high shade tolerance, and ability to alter the dynamics of soil $\mathrm{N}$ in its invaded habitat. The altered ecosystem processes and soil chemistry thus create a set of environmental conditions that will deter the growth of RM, a highly successful species in eastern North America, and be conducive to further spreading of NM itself. There are a number of other characteristics, including prolific seed production 
(Mitchell and Wilkinson 1982), dominance over native shade-tolerant tree species (Webster et al. 2005), long distance of seed dispersal for a large seed mass (Matlack 1987), greater success than its congeneric species in germination, survival and early growth of seedlings in the face of global environmental changes (Carón et al. 2015b; Karmalkar and Bradley 2017), and lower herbivory than its native congeneric species (Cincotta et al. 2009), that will increase the competitiveness of NM over the native species in eastern North America. Taking all biotic and abiotic factors into consideration, it is predicted that NM will increase its expansion and pose a greater threat to the integrity of eastern hardwood forests of North America in the future.

\section{Abbreviations}

CEC: Cation exchange capacity; ERH: Enemy release hypothesis; LAI: Leaf area index; MMH: Microbial mediation hypothesis; NFH: Novel function hypothesis; NM: Norway maple; $\mathrm{NM}_{\text {mix }}$ : Norway maple in the mixed forest; $N M_{\text {mon: }}$ Norway maple in the monospecific stand; RM: Red maple; $\mathrm{RM}_{\text {mix }}$ : Red maple in the mixed forest; $\mathrm{SCH}$ : Superior competitor hypothesis; SD: Standard Deviation; SOM: Soil organic matter

\section{Acknowledgments}

The authors thank Dr. Jessica Gurevitch for constant support and intellectual stimulation during the field experiment. The advice provided by Robert Sokal, James Thompson, Marie-Josee Fortin, and Jonathan Adams on data analysis and manuscript preparation is gratefully acknowledged. We give heartfelt thanks to Zhi-Guo Huang, Geng-Xin Chen and other vulunteers for their selfless support. The authors thank two anonymous reviewers and the journal editors for their constructive suggestions that have greatly improved the quality of the manuscript.

\section{Authors' contributions}

WF conceived, designed, and conducted the field experiment. WF and XZW analyzed the data and wrote the manuscript. Both authors provided editorial revision. Both authors read and approved the final manuscript.

\section{Funding}

WF received funding for the field study from Sigma Xi, Association of Women in Sciences and International Society of Arboriculture. WF is currently supported by NSF 18-600 Program (ID: 1921773) and National Natural Science Foundation of China Major International Joint Research Project (ID: 81620108010).

\section{Availability of data and materials}

All data generated or analyzed during this study are included in this published article.

\section{Ethics approval and consent to participate}

Not applicable.

\section{Consent for publication}

Not applicable.

\section{Competing interests}

The authors declare that they have no competing interests.

\section{Author details}

${ }^{1}$ Department of Ecology and Evolution, Stony Brook University, 650 Life Sciences Building, Stony Brook, New York 11794, USA. ${ }^{2}$ Present address: School of Earth and Environmental Sciences, Queens College, City University of New York, 65-30 Kissena Boulevard, Flushing, New York 11367, USA. ${ }^{3}$ Department of Biology, Indiana University-Purdue University Indianapolis, 723 West Michigan Street, Indianapolis, IN 46202-5132, USA.
Received: 23 October 2019 Accepted: 9 January 2020

Published online: 03 March 2020

\section{References}

Abrams MD (1992) Fire and the development of oak forests. BioScience 42:346353

Abrams MD (1998) The red maple paradox — what explains the widespread expansion of red maple in eastern forests? BioScience 48:355-366

Adams JM, Fang W, Callaway RM, Cipollini D, Newell E (2009) A cross-continental test of the enemy release hypothesis: leaf herbivory on Acer platanoides (L.) is three times lower in North America than in its native Europe. Biol Invasions 11:1005-1016

Adams MA, Attiwill PM (1982) Nitrogen mineralization and nitrate reduction in forests. Soil Biol Biochem 14:197-202

Allison PD (1995) Survival analysis using the SAS system: a practical guide. SAS Institute Inc., Cary

Bauer JT (2012) Invasive species: "back-seat drivers" of ecosystem change? Biol Invasions 14:1295-1304

Belnap J, Phillips SL, Sherrod SK, Moldenke A (2005) Soil biota can change after exotic plant invasion: does this affect ecosystem processes? Ecology 86: 3007-3017

Bolker BM, Pacala SW, Bazzaz FA, Canham CD, Levin SA (1995) Species diversity and ecosystem response to carbon dioxide fertilization: conclusions from a temperate forest model. Glob Chang Biol 1:373-381

Carón MM, De Frenne P, Brunet J, Chapbrerie O, Cousins SAO, De Backer L, Decocq G, Diekmann M, Heinken T, Kolb A, Naaf T, Plue J, Selvi F, Strimbeck GR, Wulf M, Verheyen K (2015b) Interacting effects of warming and drought on regeneration and early growth of Acer pseudoplatanus and A. platanoides. Plant Biol 17:52-62

Carón MM, De Frenne P, Chabrerie O, Cousins SA, De Backer L, Decocq G, Diekmann M, Heinken T, Kolb A, Naaf T, Plue J (2015a) Impacts of warming and changes in precipitation frequency on the regeneration of two Acer species. Flora 214:24-33

Center TD, Purcell MF, Pratt PD, Rayamajhi MB, Tipping PW, Wright SA, Dray FA (2012) Biological control of Melaleuca quinquenervia: an Everglades invader. BioControl 57:151-165

Cincotta CL, Adams JM, Holzapfel C (2009) Testing the enemy release hypothesis: a comparison of foliar insect herbivory of the exotic Norway maple (Acer platanoides L.) and the native sugar maple (A. saccharum L.). Biol Invasions 11:379-388

Crawford KM, Knight TM (2017) Competition overwhelms the positive plant-soil feedback generated by an invasive plant. Oecologia 183:211-220

Cronk QCB, Fuller JL (2001) Plant invaders: the threat to natural ecosystems. Earthscan Publications, London

Dukes JS, Pontius J, Orwig DA, Garnas JR, Rodgers VL, Brazee NJ, Cooke BJ, Theoharides KA, Stange EE, Harrington RA, Ehrenfeld JG, Gurevitch J, Lerdau M, Stinson K, Wick R, Ayres MP (2009) Responses of insect pests, pathogens and invasive species to climate change in the forests of northeastern North America: what can we predict? Can J For Res 39: $231-248$

Ehrenfeld JG (2003) Effects of exotic plant invasions on soil nutrient cycling processes. Ecosystems 6:503-523

Ehrenfeld JG (2010) Ecosystem consequences of biological invasions. Annu Rev Ecol Evol Syst 41:59-80

Ehrenfeld JG, Kourtev P, Huang W (2001) Changes in soil functions following invasions of exotic understory plants in deciduous forests. Ecol Appl 11: $1287-1300$

Ehrenfeld JG, Ravit B, Elgersma K (2005) Feedback in the plant-soil system. Annu Rev Environ Resour 30:75-115

Ehrenfeld JG, Scott N (2001) Invasive species and the soil: effects on organisms and ecosystem processes. Ecol Appl 11:1259-1260

Evans RD, Rimer R, Sperry L, Belnap J (2001) Exotic plant invasion alters nitrogen dynamics in an arid grassland. Ecol Appl 11:1301-1310

Fang W (2005) Spatial analysis of an invasion front of Acer platanoides: dynamic inferences from static data. Ecography 28:283-294

Fang W, Wang X (2011) Impact of invasion of Acer platanoides on canopy structure and understory seedling growth in a hardwood forest in North America. Trees 25:455-464

Fine PVA (2002) The invasibility of tropical forests by exotic plants. J Trop Ecol 18 687-705 
Finzi AC, Breemen NV, Canham CD (1998) Canopy tree-soil interactions within temperate forests: species effects on soil carbon and nitrogen. Ecol Appl 8: 440-446

Frazer GW, Canham CD, Lertzman KP (1999) Gap light analyzer (GLA). Version 2.0: imaging software to extract canopy structure and gap light transmission indices from true-colour fisheye photographs, users manual and program documentation. Simon Fraser University and the Institute of Ecosystem Studies, Burnaby, British Columbia and Millbrook, New York

Galbraith-Kent SL, Handel SN (2008) Invasive Acer platanoides inhibits native sapling growth in forest understorey communities. J Ecol 96:293-302

Gomez-Aparicio L, Canham CD, Martin PH (2008) Neighbourhood models of the effects of the invasive Acer platanoides on tree seedling dynamics: linking impacts on communities and ecosystems. J Ecol 96:78-90

Grant TAl, Paschke MW (2012) Invasive plant impacts on soil properties nutrient cycling and microbial communities. In: Monaco TA, Sheley RL (eds) Invasive plant ecology and management, linking processes to practice. $C A B$ International, Cambridge, pp 79-104

Hart SC, Stark JM, Davidson EA, Firestone MK (1994) Nitrogen mineralization, immobilization, and nitrification. In: Weaver RW, Angle JS, Bottomley PJ et al (eds) Methods of soil analysis: part 2-microbiological and biochemical properties. Soil Science Society of America, Madison, pp 985-1018

Jarrell WM, Armstrong DE, Grigal DF, Kelly EF, Monger HC, Wedin DA (1999) Soil water and temperature status. In: Robertson GP, Coleman DC, Bledsoe CS, Sollins P (eds) Standard soil methods for long-term ecological research. Oxford University Press, New York, pp 55-73

Jo I, Fridley JD, Frank DA (2017) Invasive plants accelerate nitrogen cycling: evidence from experimental woody monocultures. J Ecol 105:1105-1110

Kandlikar GS, Johnson CA, Yan X, Kraft NJ, Levine JM (2019) Winning and losing with microbes: how microbially mediated fitness differences influence plant diversity. Ecol Lett 22:1178-1191

Karmalkar AV, Bradley RS (2017) Consequences of global warming of $1.5^{\circ} \mathrm{C}$ and 2 ${ }^{\circ} \mathrm{C}$ for regional temperature and precipitation changes in the contiguous United States. PLoS One 12(1):e0168697. https://doi.org/10.1371/journal.pone. 0168697

Kourtev PS, Ehrenfeld JG, Haggblom M (2002) Exotic plant species alter the microbial community structure and function in the soil. Ecology 83:31523166

Lau JA, Suwa T (2016) The changing nature of plant-microbe interactions during a biological invasion. Biol Invasions 18:3527-3534

Levine JM, Pachepsky E, Kendall BE, Yelenik SG, Lambers JHR (2006) Plant-soil feedbacks and invasive spread. Ecol Lett 9:1005-1014

Levine JM, Vila M, Antonio CMD, Dukes JS, Grigulis K, Lavorel S (2003) Mechanisms underlying the impacts of exotic plant invasions. Proc R Soc B 270:775-781

Li W, Zhang C, Jiang H, Xin G, Yang Z (2006) Changes in soil microbial community associated with invasion of the exotic weed, Mikania micrantha H.B.K. Plant Soil 281:309-324

Liao C, Peng R, Luo Y, Zhou X, Wu X, Fang C, Chen J, Li B (2008) Altered ecosystem carbon and nitrogen cycles by plant invasion: a meta-analysis. New Phytol 177:706-714

Mack MC, D'Antonio CM, Ley RE (2001) Alteration of ecosystem nitrogen dynamics by exotic plants: a case study of $C_{4}$ grasses in Hawaii. Ecol Appl 11: 1323-1335

Mack RN, Simberloff D, Lonsdale WM, Evans H, Clout M, Bazzaz FA (2000) Biotic invasions: causes, epidemiology, global consequences, and control. Ecol Appl 10:689-710

Martin PH (1999) Norway maple (Acer platanoides) invasion of a natural forest stand: understory consequence and regeneration pattern. Biol Invasions 1: 215-222

Martin PH, Marks PL (2006) Intact forests provide only weak resistance to a shade-tolerant invasive Norway maple (Acer platanoides L.). J Ecol 94:10701079

Matlack GR (1987) Diaspore size, shape, and fall behavior in wind-dispersed plant species. Am J Bot 74:1150-1160

Meekins JF, McCarthy BC (2001) Effects of environmental variation on the invasive success of a nonindigenous forest herb. Ecol Appl 11:1336-1348

Mitchell A, Wilkinson J (1982) The trees of Britain and northern Europe. Collins, London

Muller CH (1969) Allelopathy as a factor in ecological process. Vegetatio 1:348-357

Musil CF (1993) Effect of invasive Australian acacias on the regeneration, growth and nutrient chemistry of South African lowland fynbos. J Appl Ecol 30:361-372
O'Neill RV, Ausmus BS, Jackson DR, Van Hook RJ, Van Voris P, Washburne C, Watson AP (1977) Monitoring terrestrial ecosystems by analysis of nutrient export. Water Air Soil Pollut 8:271-277

Parker IM, Simberloff D, Lonsdale WM, Goodell K, Wonham M, Kareiva PM, Williamson MH, Holle BV, Moyle PB, Byers JE, Goldwasser L (1999) Impact: toward a framework for understanding the ecological effects of invaders. Biol Invasions 1:3-19

Peng S, Kinlock NL, Gurevitch J, Peng S (2019) Correlation of native and exotic species richness: a global meta-analysis finds no invasion paradox across scales. Ecology 100(1):e02552

Raison RJ, Connell MJ, Khanna PK (1987) Methodology for studying fluxes of soil mineral-N in situ. Soil Biol Biochem 19:521-530

Reich P, Grigal DF, Aber JD, Gower ST (1997) Nitrogen mineralization and productivity in 50 hardwood and conifer stands on diverse soils. Ecology 78 : 335-347

Robertson GP, Wedin D, Groffman PM, Blaire JM, Holland EA, Nadelhoffer K, Harris D (1999) Soil carbon and nitrogen availability: nitrogen mineralization, nitrification, and soil respiration potentials. In: Robertson GP, Coleman DC, Bledsoe CS, Sollins P (eds) Standard soil methods for long-term ecological research. Oxford University Press, New York, pp 258-271

Rodgers VL, Wolfe BE, Werden LK, Finzi AC (2008) The invasive species Alliaria petiolata (garlic mustard) increases soil nutrient availability in northern hardwood-conifer forests. Oecologia 157:459-471

Rodrigues RR, Pineda RP, Barney JN, Nilsen ET, Barrett JE, Williams MA (2015) Plant invasions associated with change in root-zone microbial community structure and diversity. PLoS One. https://doi.org/10.1371/journal.pone.0141424

Scott NA, Saggar S, McIntosh PD (2001) Biogeochemical impact of Hieracium invasion in New Zealand's grazed tussock grasslands: sustainability implications. Ecol Appl 11:1311-1322

Sher AA, Marshall DL, Taylor JP (2002) Establishment patterns of native Populus and Salix in the presence of invasive nonnative Tamarix. Ecol Appl 12:760-772

Shouman S, Mason N, Kicheya T, Closset-Koppa D, Heberling MJ, Kobeissid A, Decocqa G (2017) Functional shift of sycamore maple (Acer pseudoplatanus) towards greater plasticity and shade tolerance in its invasive range. Perspect Plant Ecol Evol Syst 29:30-40

Sokal RR, Rohlf FJ (2003) Biometry. In: Biometry, 3rd edn. W.H. Freeman and Company, New York

Stenburg P, Linder S, Smolander H, Flower-Ellis J (1994) Performance of the LAI2000 plant canopy analyzer in estimating leaf area index of some scots pine stands. Tree Physiol 14:981-995

Stokes ME, Davis CS, Koch GG (1995) Categorical data analysis using the SAS system. SAS Institute. Inc., Cary

Suding KN, Harpole WS, Fukami T, Kulmatiski A, MacDougall AS, Stein C, Van der Putten WH (2013) Consequences of plant-soil feedbacks in invasion. J Ecol 101:298-308

Vitousek PM (1990) Biological invasions and ecosystem processes: towards an integration of population biology and ecosystem studies. Oikos 57:7-13

Vitousek PM (2012) Biological invasions and ecosystem properties: can species make a difference? In: Mooney HA, Drake JA (eds) Ecology of biological invasions of North America and Hawaii. Springer Verlag, New York, pp 163-176

Vitousek PM, D'Antonio CM, Loope LL, Rejmaek M, Westbrooks R (1997) Introduced species: a significant component of human-caused global change. New Zeal J Ecol 21:1-16

Vitousek PM, Walker LR (1989) Biological invasion by Myrica faya in Hawai'i: plant demography, nitrogen fixation, ecosystem effects. Ecol Monogr 59:247-265

von Ende CN (2001) Repeated-measures analysis: growth and other timedependent measures. In: Scheiner SM, Gurevitch J (eds) Design and analysis of ecological experiments. Chapman \& Hall, New York, pp 113-137

Von Holle B, Delcourt HR, Simberloff D (2003) The importance of biological inertia in plant community resistance to invasion. J Veg Sci 14:425-432

Walsh JR, Carpenter SR, Vander Zanden MJ (2016) Invasive species triggers a massive loss of ecosystem services through a trophic cascade. Proc Natl Acad Sci 113:4081-4085

Webb SL, Kaunzinger CK (1993) Biological invasion of the Drew University (new Jersey) forest preserve by Norway maple ( Acer platanoides L.). Bull Torrey Bot Club 120:343-349

Webster CR, Nelson K, Wangen SR (2005) Stand dynamics of an insular population of an invasive tree, Acer platanoides. Forest Ecol Manag 208:85-99

Wedin DA, Tilman D (1990) Species effects on nitrogen cycling: a test with perennial grasses. Oecologia 84:433-441 
Welles JM, Norman JM (1991) Instrument for indirect measurement of canopy architecture. Agron J 83:818-825

Wolfe BE, Klironomos J (2005) Breaking new ground: soil communities and exotic plant invasion. BioScience 55:477-487

\section{Publisher's Note}

Springer Nature remains neutral with regard to jurisdictional claims in published maps and institutional affiliations.

Submit your manuscript to a SpringerOpen ${ }^{\mathcal{O}}$ journal and benefit from:

- Convenient online submission

- Rigorous peer review

- Open access: articles freely available online

- High visibility within the field

- Retaining the copyright to your article

Submit your next manuscript at $\boldsymbol{\nabla}$ springeropen.com 